\title{
反磁性流体における磁気熱対流の過渡特性 \\ Transient Characteristics of Magnetothermal Convection in Diamagnetic Fluid
}

\author{
○正 赤松 正人（秋県大） 正 日向野 三雄（秋県大） 正 高橋 義雄（秋県大） 正 尾添 紘之（九大） \\ Masato AKAMATSU, Mitsuo HIGANO and Yoshio TAKAHASHI, Akita Prefectural University, Honjo, Akita \\ Hiroyuki OZOE, Institute for Materials Chemistry and Engineering, Kyushu University, Kasuga, Fukuoka
}

\begin{abstract}
We numerically simulated how magnetizing force affects the natural convection of water with the diamagnetic property in a vertical cylindrical container heated from below and cooled from above. When the circular electric coil was placed at the lower end plate heated isothermally, the average Nusselt number in the system with the magnetic field decreased in comparison with that in the system without the magnetic field so that natural convection was suppressed by the magnetizing force. When the circular electric coil was placed at the upper end plate cooled isothermally, the reverse tendency was computed. Furthermore, to understand the mechanism of the generation of the magnetothermal convection induced by the magnetizing force, the variety of magnetothermal convection to the steady state was visualized under two different initial conditions.
\end{abstract}

Key Words: Magnetothermal Convection, Magnetizing Force, Natural Convection, Water, Diamagnetic Fluid

\section{1. 緒言}

本研究は，これまで磁場とは無関係と考えられてきた水 のような非導電性で反磁性の性質を示す熱対流を磁場によ つて制御しようとするものである。この種の研究として，

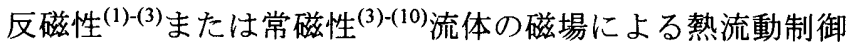
に関する報告があるが，十分に議論されているとはまだま だ言い難い，そこで，本報では磁場および温度勾配が付与 された竪型円筒容器内における水の磁気熱対流の定常特性 および過渡特性を数值解析によって詳細に調べたので報告 する.

\section{2. 無次元基礎方程式}

式(1)-(3)は, 無次元化された連続の式, 反磁性流体に対

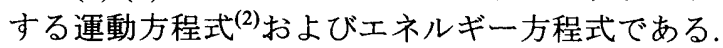

$\nabla \cdot \vec{U}=0$

$D \vec{U} / D \tau=-\nabla P+\operatorname{Pr} \nabla^{2} \vec{U}-(y / 2) \operatorname{RaPr} T \nabla B^{2}+\operatorname{RaPr} T(0,0,1)^{T}$

$D T / D \tau=\nabla^{2} T$

以下は，上式の無次元化に用いた無次元数である.

$$
\begin{aligned}
& R=\frac{r}{r_{0}}, \quad Z=\frac{z}{r_{0}}, \quad \tau=\frac{t}{t_{0}}, \quad \vec{U}=\frac{u}{u_{0}}, \quad P=\frac{p^{\prime}}{p_{0}}, \quad T=\frac{\theta-\theta_{0}}{\theta_{h}-\theta_{c}}, \\
& H=\frac{h}{r_{0}}, \quad \vec{B}=\frac{\vec{b}}{b_{0}}, \quad R a=\frac{g \beta\left(\theta_{h}-\theta_{c}\right) r_{0}{ }^{3}}{\alpha v}, \quad \operatorname{Pr}=\frac{v}{\alpha}, \quad \gamma=\frac{\chi b_{0}{ }^{2}}{\xi g r_{0}} .
\end{aligned}
$$

$\gamma$ は磁場の強さを示す. 基準量は以下のように定義した. $r_{0}=h, \quad u_{0}=\alpha / r_{0}, \quad t_{0}=r_{0} / u_{0}, \quad \theta_{0}=\left(\theta_{h}+\theta_{c}\right) / 2, \quad p_{0}=\rho_{0} u_{0}{ }^{2}, \quad b_{0}=\xi_{i} / r_{0}$. なお, $h[\mathrm{~m}]$ は容器半径, $x$ は流体の質量磁化率 $\left[\mathrm{m}^{3} / \mathrm{kg}\right], \xi$ は真空の透磁率，などである。

\section{3. 解析モデルおよび解析方法}

Fig.1 に，解析モデルを示す.これは，水で満たされた堅 型円筒容器が超伝導磁石内のボア内に設置されていること を想定している. 容器は一定温度で底面から加熱, 上面か ら冷却され, 側壁は断熱されている.また, 容器半径の 2.5 倍の径を有する一巻き円形電磁コイルが，加熱面または冷 却面のどちらかに置かれた。ここで，このコイルに定常電 流が流れることによって発生する磁束密度の分布は, 式(4) に示す Biot-Savart の法則から計算した。

$\vec{B}=-\frac{1}{4 \pi} \oint \frac{\vec{R} \times d \vec{S}}{R^{3}}$

以下に，二つの異なる初期条件，境界条件を示す。ここで， 本数值解析では速度場, 温度場は軸対称であると仮定し, 式(1)-(3)中の周方向の勾配をゼロとした.
初期条件 A

$$
\mathrm{T}=\mathrm{U}=\mathrm{W}=0 \quad \text { at } \quad \tau=0 .
$$

初期条件 B

The convergence solution of natural convection computed for $\mathrm{Ra}=10^{4}, \operatorname{Pr}=5.85$ and $\gamma=0$

境界条件

$$
\begin{aligned}
& \mathrm{T}=+0.5, \mathrm{U}=\mathrm{W}=0 \text { at } 0 \leqq \mathrm{R}<\mathrm{H} \text { and } \mathrm{Z}=0 . \\
& \mathrm{T}=-0.5, \mathrm{U}=\mathrm{W}=0 \text { at } 0 \leqq \mathrm{R}<\mathrm{H} \text { and } \mathrm{Z}=2 \mathrm{H} . \\
& \partial \mathrm{T} / \partial \mathrm{R}=0, \mathrm{U}=\mathrm{W}=0 \text { at } \mathrm{R}=\mathrm{H} \text { and } 0<\mathrm{Z}<2 \mathrm{H} .
\end{aligned}
$$

\section{4. 解析結果}

Fig.2 は，磁場が印加されていない時の定常状態における 速度場と温度場である. 解析条件は, 初期条件 A でかつ $\gamma$ $=0, \mathrm{Ra}=10^{4}, \mathrm{Pr}=5.85$ である. 典型的な自然対流の定常熱 流動場が計算された. 具体的には, 底面で加熱された高温 流体が側壁に沿って上昇し, 上面で冷却された低温流体が 中心付近において下降する熱流動場である, この時, 加熱 面での平均 $\mathrm{Nu}$ 数 $\left(\mathrm{Nu}_{\mathrm{hot}}\right)$ は 3.423, 冷却面でのそれ $\left(\mathrm{Nu}_{\mathrm{cold}}\right)$ は3.436であった。これらの比 $\left(\mathrm{Nu}_{\text {cold }} / \mathrm{Nu}_{\text {hot }}\right)$ は 1.004 に なる. 故に, 系内の熱バランスはほぼ保たれていると考え られる. 従って, 以後の磁場下における数值解析において も半径方向に 32, 軸方向に 64 の不等間隔格子を用いた.

Fig.3 は, 磁場が印加された時の定常状態における磁気熱 対流の速度場と温度場である. 解析条件は, 初期条件 A で かつ $\gamma=-200, \mathrm{Ra}=10^{4}, \mathrm{Pr}=5.85$ である. コイルは, 左図で は底面の加熱面 $\left(Z_{\mathrm{co}}=0\right)$, 右図では上面の冷却面 $\left(Z_{\mathrm{co}}=2\right)$ に 置かれている.コイルを加熱面に置いたとき, 磁化力の作 用により自然対流は抑制され磁気熱対流は殆ど発生しなか った。このため，伝熱はほぼ熱伝導に支配され， $\mathrm{Nu}_{\text {hot }}$ は 1.135 であった。一方，コイルを冷却面に置いたとき，磁 化力の作用により自然対流が促進された。この時， $\mathrm{Nu}_{\text {hot }}$ は6.385であり，Fig.2に示した自然対流のそれと比較する と約 1.9 倍になった. このように, 非一様磁場の印加によ って発生する磁気熱対流の強さはコイルの設置位置に強く 依存することがわかった，次に，磁気熱対流がどのように 発達するのかを調べるために，過渡期の熱流動場を可視化 した.さらに，初期条件の効果についても検討した。

Fig.4は, 磁場が印加された時の無次元時刻 $\tau=0.025$ に おける過渡期の磁気熱対流の速度場と温度場である。解析 条件は, 初期条件 A でかつ $\gamma=-200, \mathrm{Ra}=10^{4}, \mathrm{Pr}=5.85$ であ る.コイルは, 左図では加熱面, 右図では冷却面に置かれ 
ている.なお，これら二つの速度べクトル線図は，Fig.3の 5 倍の大きさで描かれている。まず，左図に示すようにコ イルを底面の加熱面に置いてステップ的に磁場を印加して 温度差を与えると, 磁気熱対流は初め加熱面近傍で誘起さ れた。そして，十分時間が経過した定常状態においても Fig.3 の左図に示したように殆ど対流は発達しなかった。一 方，右図に示すようにコイルを上面の冷却面に置いてステ ップ的に磁場を印加して温度差を与えると, 冷却面近傍で 強い磁気熱対流が誘起された。 その後, この対流は時間と ともにどんどん発達し噴流のように加熱面に衝突した。 そ して, 十分時間が経過した定常状態において Fig. 3 の右図 に示した熱流動場が形成された。

Fig.5 は，Fig.4 と同様の速度場と温度場であるが，初期 条件 B（Fig.2 に示した自然対流の定常熱流動場の収束解） の解析結果である.なお, 左図の速度べクトル線図は, Fig.3 の 5 倍の大きさで描かれている。まず，左図に示すように コイルを底面の加熱面に置いてステップ的に磁場を印加す ると, 自然対流とは逆向きの磁気熱対流が誘起された。 そ の後, この対流は時間とともに徐々に減衰した。 そして, 十分時間が経過した定常状態で Fig.3 の左図と同様の熱流 動場が形成された. 一方, 右図に示すようにコイルを上面 の冷却面に置いてステップ的に磁場を印加すると, Fig.2に 示した自然対流と同様のフローパターンをもった熱流動場 が観察されたが，この対流は自然対流よりも強いものであ る. そして, 十分時間が経過した定常状態で Fig.3 の右図 と同様の熱流動場が形成された。このように，初期条件 A と B の定常状態における磁気熱対流は完全に一致し, 初期 条件に依存しないことがわかった。

\section{5. 結言}

磁場および温度勾配が付与された堅型円筒容器内におけ る反磁性の性質を持った水の磁気熱対流の定常特性および 過渡特性を数值解析的に検討した。この結果, コイルを加 熱面に設置すると熱伝達は抑制され，冷却面に設置すると 熱伝達は促進された. また, 過渡変化から磁気熱対流の発 生メカニズムを理解することができた。

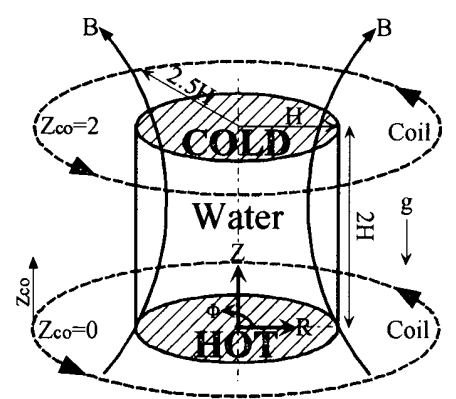

Fig.1 Schematic representation of the model system.

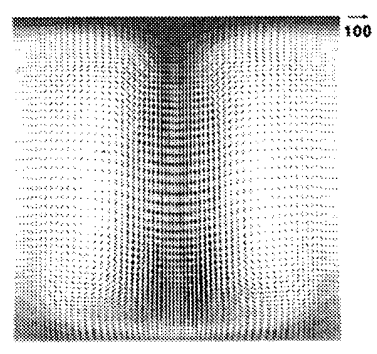

Fig. 2 Temperature and velocity fields at a steady state in the system without the magnetic field for $\mathrm{Ra}=10^{4}, \mathrm{Pr}=5.85$ and $\gamma=0$ under the initial condition A.



Fig.3 Magnetothermal convection at a steady state for $\gamma=$ $-200, \mathrm{Ra}=10^{4}, \operatorname{Pr}=5.85$ and $\mathrm{Z}_{\mathrm{co}}=0$ (left), $\mathrm{Z}_{\mathrm{co}}=2$ (right) under the initial condition $\mathrm{A}$.


Fig.4 Transient magnetothermal convection at $\tau=0.025$ for $y=-200, \operatorname{Ra}=10^{4}, \operatorname{Pr}=5.85$ and $Z_{\mathrm{co}}=0$ (left), $Z_{\mathrm{co}}=2$ (right) under the initial condition $\mathrm{A}$.


Fig.5 Transient magnetothermal convection at $\tau=0.025$ for $\gamma=-200, \operatorname{Ra}=10^{4}, \operatorname{Pr}=5.85$ and $Z_{\mathrm{co}}=0$ (left), $Z_{\mathrm{co}}=2$ (right) under the initial condition $\mathrm{B}$.

参考文献

(1) Qi, J. et al., J. Crystal Growth, 204 (1999), 408.

(2) Tagawa, T. et al., Int. J. Heat Mass Transf., 46 (2003), 4097.

(3) Akamatsu, M. et al., IEEE TRANSACTION on Applied Superconductivity, 14 (2004), 1674.

(4) Braithwaite, D. et al., Nature, 354 (1991), 134.

(5) Bai, B. et al., AIAA J., 37 (1999), 1538.

(6) Qi, J. et al., Int. J. Heat Mass Transf., 44 (2001), 3043.

(7) Tagawa, T. et al., Int. J. Heat Mass Transf., 45 (2002), 267.

(8) Kaneda, M. et al., J. Heat Transfer, 124 (2002), 17.

(9) Maki, S. et al., J. Heat Transfer, 124 (2002), 667.

(10) Akamatsu, M. et al., Num. Heat Transfer A, 43 (2003), 9. 